\title{
A comparative study on the treatment performance of a conventional septic tank system and reed bed-soil absorption system receiving domestic effluent
}

\author{
Niall O'Luanaigh ${ }^{\mathrm{a} *}$, Paul Johnston ${ }^{\mathrm{a}}$, Bruce Missteara, Titiksh Patel ${ }^{\mathrm{b}}$, Laurence Gill ${ }^{\mathrm{a}}$ \\ ${ }^{a}$ Environmental Engineering Group, Department of Civil, Structural and Environmental Engineering, Trinity College, \\ Dublin 2, Ireland \\ Tel.+353 (1) 8962045,+353 (1) 8961047; Fax+353 (1) 677 3072; email: noluanai@tcd.ie or gilll@tcd.ie \\ ${ }^{b}$ RPS Engineering, West Pier Business Campus, Dun Laoghaire, Co Dublin, Ireland
}

Received 28 April 2008; Accepted in revised form 18 September 2008

\section{A B S T R A C T}

In Ireland, the most prevalent domestic wastewater treatment application in unsewered areas is the conventional septic tank system comprising of septic tank and soil absorption system, the latter more commonly referred to as a percolation area in Ireland. Recent concern has been expressed over the discharge of on-site effluent to highly permeable soils which, although permitted in current Irish EPA guidelines, has generated debate as to whether an insufficient level of treatment in the subsoil's vadose zone is being achieved. In situations where a septic tank installation is considered unsuitable according to a rigorous site assessment, a secondary treatment system such as a horizontal subsurface-flow reed bed can be installed to improve the effluent quality before discharge to the subsoil. On-site research was thus carried out to assess and compare the treatment capabilities of freely-draining subsoils receiving both septic tank and secondary effluents in tandem with a treatment assessment of a horizontal subsurface-flow reed bed. Results over an 18-month period have shown the HF reed bed to perform poorly with removal of only $52 \%$ of the organic load. An impressive $1.9 \mathrm{log}$-unit removal in E. coli was nevertheless achieved. The majority of nitrification is seen to occur in the first $0.35 \mathrm{~m}$ of subsoil for all sets of percolation trenches and, while coupled with poor denitrification throughout the subsoil, has compromised groundwater quality in the form of nitrate infiltration. The research also shows that in general the septic tank effluent has received a comparable quality to the secondary effluent in terms of N-loading and $E$. coli occurrence by the time the point of potential discharge to groundwater is reached in the subsoil.

Keywords: On-site wastewater treatment (OWTS); Septic tank effluent (STE); Secondary effluent (SE); Percolation area; Freely draining; Horizontal subsurface flow (HF) reed bed

\section{Introduction}

Over one third of the population in Ireland, or 400,000 dwellings, rely on on-site systems to treat their domestic wastewater [1]. Traditionally, an on-site wastewater treatment system (OWTS) comprises of a septic tank for primary treatment of raw wastewater followed by infiltra-

\footnotetext{
* Corresponding author.
}

tion and percolation through soil, which acts as a porous media biofilter for the attenuation of the wastewaters' pollutants prior to groundwater recharge. Given that over $25 \%$ of all our water supply is currently provided by groundwater [2], it is critical to protect this resource from contamination since the percolate released from OWTSs enter the underlying groundwater which can, in turn, migrate under natural gradients toward points of exposure for receptors of concern, e.g. humans and drink- 
ing water supplies [3]. As such, it is role of the percolation area and its inherent subsoil characteristics to provide a sufficient contaminant attenuation zone and ensure long-term protection from groundwater pollution.

Ireland's Environmental Protection Agency [4] has published recommendations aimed at defining subsoil conditions that will provide an acceptable level of treatment for on-site wastewater in order to protect groundwater resources from contamination. One of the crucial elements of this risk assessment approach is the percolation test. This is required to ascertain the assimilation capacity of the subsoil and is represented in terms of a 'T-value', obtained from the standard falling head percolation test [5]. A low T-value (1 to 5) denotes a coarsegrained soil that is highly permeable in nature - typically sand or gravel, while a high T-value (40-50) is more indicative of a less permeable clay-based soil. Currently, one of the growing concerns amongst water authorities, practitioners and other bodies surrounds the discharge of on-site effluent into the more freely draining soils (with T-values of between 1 and 5), where although permitted under the current guidelines, there exists an intuitive feeling that the effluent is percolating at an excessive rate. This ultimately creates the risk of insufficient nutrient and pathogenic removal in the subsoil's vadose zone and an increased potential for groundwater contamination. Many studies have highlighted the importance in the formation and development of a clogging layer, or biomat, at the infiltrative surface along the base and wetted sides of the percolation trenches and deemed it to be a crucial factor in the retention of the effluents' constituents [6-8]. These clogged infiltrative surface zones are characterised by elevated organic matter accumulations, high water content and high microbial densities. Not only does it reduce the rate of infiltration and thereby contribute to unsaturated flow in the underlying soil profile, it can be more biogeochemically reactive than the natural soil and can enhance sorption, biotransformation and die-off/inactivation processes [9]. The rate and extent of the biomat development with time is thought to be dependent on several factors but namely the soil's morphology and the wastewater composition and loading rate.

Along with percolation rate compliance, current regulations for OWTSs that rely on conventional septic tank treatment followed by soil percolation specify other minimum and maximum values for many features of the system, e.g. minimum depths to groundwater and bedrock, minimum distance from drinking water wells, minimum sizing for the percolation area. When one or more of theses specifications can not be met, septic tank effluent (STE) may be deemed unsuitable for immediate discharge to a percolation area. In such cases an alternative system such as a horizontal subsurface-flow (HF) reed bed can be installed after the septic tank to provide secondary effluent prior to further treatment in the subsoil. Despite this, there is reluctance in Ireland amongst a number of water authorities to permit the use of wetlands as secondary treatment systems given the scarcity of reliable long-term performance data relevant to Ireland and its climate and their apparent poor winter treatment performance [10]. HF reed beds comprise a shallow basin lined with an impervious material which is filled with a substrate, usually gravel, and planted with vegetation tolerant of saturated conditions. The wastewater to be treated is introduced at one end and flows horizontally through the substrate below its surface before being discharged via an outlet structure. Treatment occurs as a result of a number of physical, chemical and biological processes during the water's passage through the bed [11]. HF reed beds are regarded as particularly good in the removal of $\mathrm{BOD}_{5}$ and SS. However, the majority of research to date has been carried out using domestic wastewaters with low (50-150 $\left.\mathrm{mg} \mathrm{L}^{-1}\right) \mathrm{BOD}_{5}$ inflow concentrations [12], most probably due to the use of combined (surface, rain and wastewater) sewer systems. Undiluted septic tank effluent, in comparison, has a $\mathrm{BOD}_{5}$ of between 150 and $400 \mathrm{mg} \mathrm{L}^{-1}$ [13].

Field research over an 18-month period was undertaken to examine and compare the attenuation capacity of freely-draining subsoils, with a T-value of between 1 and 5, as part of a conventional septic tank system and in treating reed bed effluent (RBE). For the latter, a gravel based horizontal subsurface-flow reed bed was constructed, with its treatment efficiency as a stand-alone system assessed in parallel. This paper details the findings over an 18-month monitoring period.

\section{Materials and methods}

\subsection{Site selection, design and construction layout}

In selecting a study site in the field to carry out the research, compliance with the EPA recommendations for site acceptability was a prerequisite. Site location and a trial hole inspection had to satisfy Groundwater Protection Schemes [1] and EPA guidelines [4]. In addition, it was essential that the subsoil had a T-value of between 1 and 5 which would indicate a highly permeable freelydraining medium. A dwelling with at least four people was also desirable to ensure a generous hydraulic loading over the whole system was maintained throughout the sampling period. The study site (Table 1) eventually selected fulfilled all the aforementioned criteria, with a household occupancy of 6 people (husband, wife and

Table 1

Study site characteristics

\begin{tabular}{ll}
\hline No. of residents & 6 \\
T-value & 4 \\
Field saturated hydraulic conductivity $\left(k_{\mathrm{fs}}\right)$ & 1.05 \\
Recorded mean daily flow per capita $\left(\mathrm{l} \mathrm{d}^{-1}\right)$ & 110.4 \\
\hline
\end{tabular}


their four teenage children) and a subsoil posting a Tvalue of 4 , equivalent to a field saturated hydraulic conductivity $\left(k_{\mathrm{fs}}\right)$ of $1.05 \mathrm{~m} \mathrm{~d}^{-1}$.

Raw wastewater from the household was firstly treated in a two-chambered septic tank of capacity $3785 \mathrm{~L}$, before the STE was evenly split two-ways via a distribution device to a set of percolation trenches and an on-site constructed HF reed bed. The partially treated effluent from the reed bed was thereafter discharged to a set of percolation trenches providing additional purification of the percolate. In essence, the site could thus be regarded and analysed as two separate treatment systems (Fig. 1):

a) a conventional septic tank system where the percolation area receives STE (half the hydraulic load)

b) a septic tank and reed bed system where the subsequent percolation area receives $\mathrm{RBE}$ (half the hydraulic load)

Combining the theory of a plug-flow $\mathrm{BOD}_{5}$ removal model (first-order kinetics) and Darcy's law yields an areal bed design figure of $5 \mathrm{~m}^{2}$ per person for secondary treatment [14]. In treating a 3-person design hydraulic load, the dimensions for the reed bed were set at $6 \times 2.5$ $\times 0.6 \mathrm{~m}(l \times b \times h)$ accordingly. The bed was sealed with an impervious butyl rubber liner and filled with $5-15 \mathrm{~mm}$ washed pea gravel (Fig. 3.). The inlet structure had dual free discharge outfalls to promote an even spread of the influent across the inlet end of the bed. A constant water level 50mm below the surface was maintained through- out by the standpipe in the outlet structure. An increased gravel size (15-30 mm) was also distributed locally around the inlet and outlet pipes to reduce the potential for clogging and blockage. The bed was then planted with Phragmites Australis (common reed) in blocks of 4 per $\mathrm{m}^{2}$.

\subsection{Field methodology}

In order to monitor the hydraulic efficiency of distribution box 1 (Fig. 1.) in splitting the flow equally, tipping bucket instrumentation with datalogger (Model $6506 \mathrm{H}$-Unidata, Australia) were installed underneath each of the four outlets of the box. This enabled a very accurate determination (to a sensitivity of one tip every $125 \mathrm{~mL}$ ) to be made of the effluent distribution to both the reed bed and percolation area. Soil moisture analysis was carried out via suction lysimeters (Soilmoisture Equipment Corporation) which were installed along the percolation trenches at nominal depths of $0.35,0.65$ and $0.95 \mathrm{~m}$ below the invert of each trench (see Figs. 1 and 2.). Given such concentrated positioning, a detailed picture of the movement, distribution and fate of the effluent in the vadose zone could be established from all sets of trenches. Careful installation of the lysimeters was paramount to avoid creating artificial preferential flowpaths (macropores) which would otherwise compromise the treatment of the percolating effluent. Groundwater monitoring boreholes immediately upstream (U/S) and downstream $(\mathrm{D} / \mathrm{S})$ of the percolation areas on both sites were

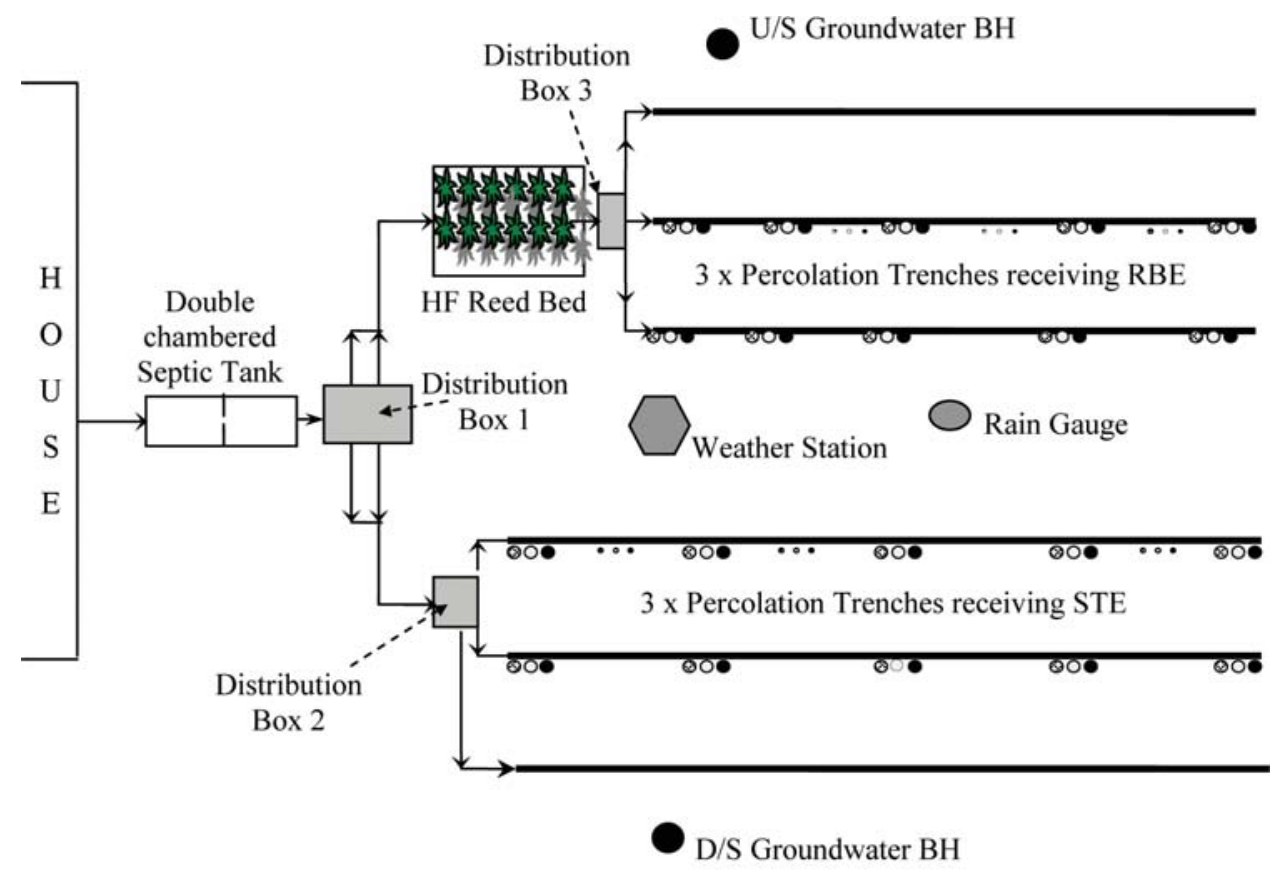

๑๐ Suction Lysimeters $(0.35 \mathrm{~m}, 0.65 \mathrm{~m}, 0.95 \mathrm{~m}$ below trench invert $)$

‥ Tensiometers $(0.35 \mathrm{~m}, 0.65 \mathrm{~m}, 0.95 \mathrm{~m}$ below trench invert $)$

Fig. 1. Schematic diagram of study site and instrumentation layout. 


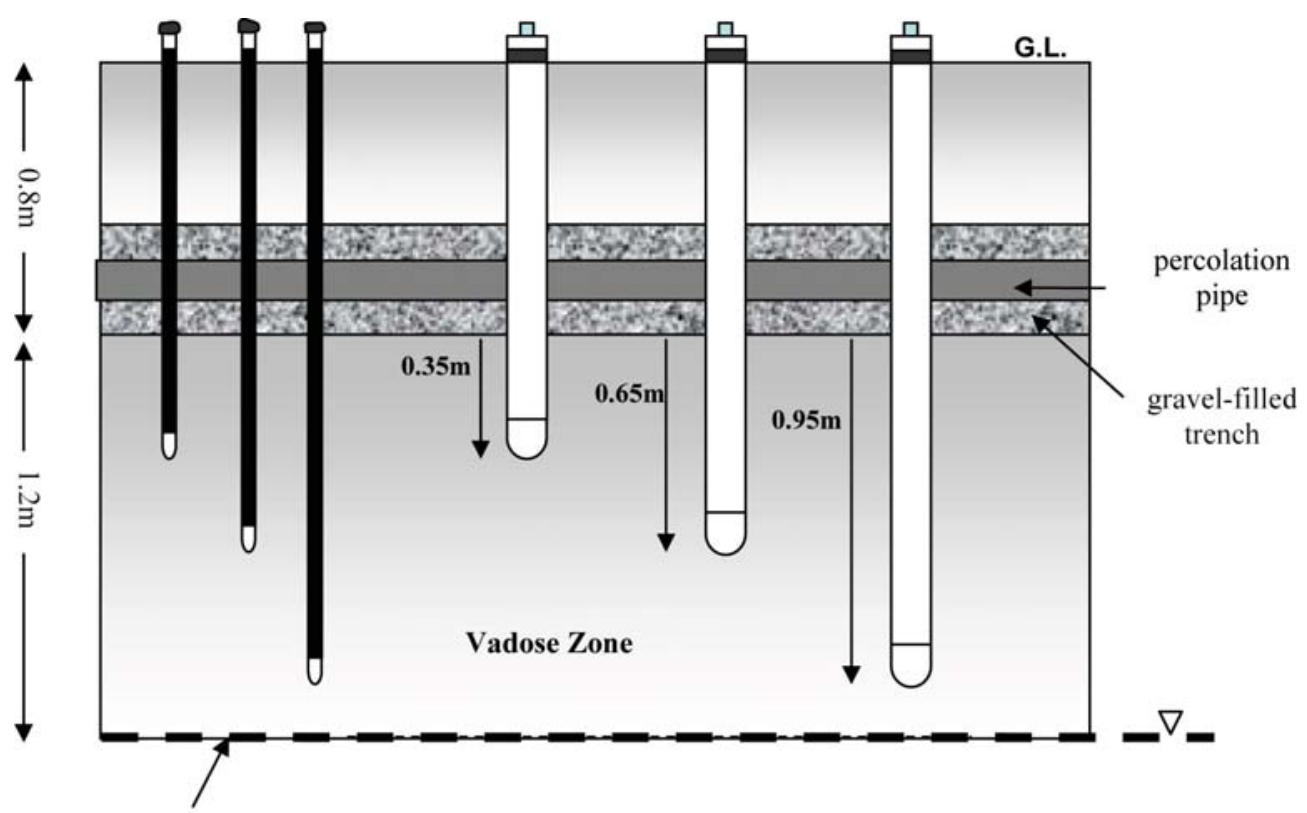

Minimum discharge point to groundwater for conventional septic tank system

Fig. 2. Cross-section of percolation trench including suction lysimeter and tensiometer profile.

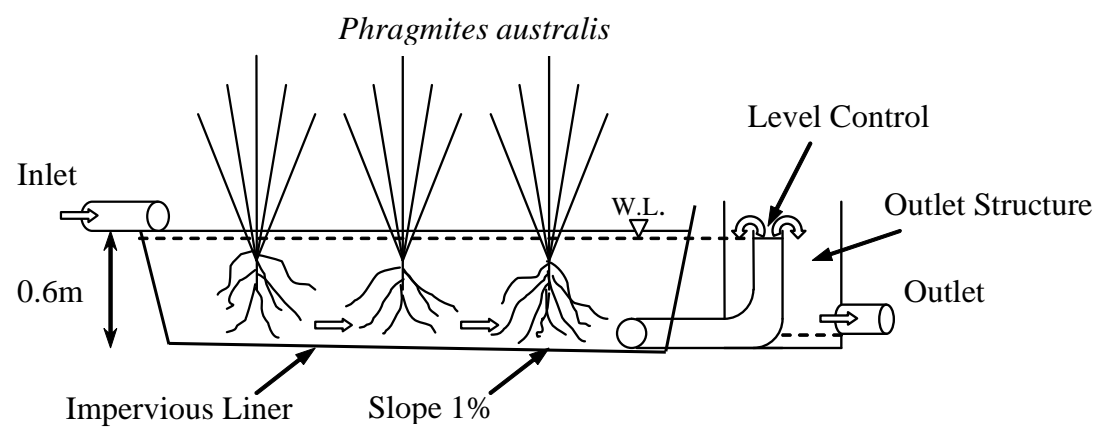

Fig. 3. Elevation of horizontal subsurface-flow reed bed treatment system.

also drilled to assess the pollutant effect of the system on the underlying aquifer. To obtain a profile of soil moisture tension, tensiometers (soil measurement systems) were installed to the three same depths as the lysimeters in the positions shown (Fig. 2). Meteorological variables (rainfall, temperature, wind speed, relative humidity, solar radiation and sunshine hours) on site were recorded by a Campbell scientific weather station and a Casella rain gauge in order to carry out appropriate mass balance analyses on the reed bed and subsoil.

\section{Analysis and results}

\subsection{Hydraulic loading}

Wastewater generation per capita is dependent on a number of factors including lifestyle, climate, time of day, year and location. In Ireland, EPA guidelines specify a value of $180 \mathrm{~L} \mathrm{~d}^{-1}$ as the typical daily hydraulic load per capita to an OWTS for single dwellings. Research has shown this figure to vary substantially with water consumption values of between 65 and $180 \mathrm{~L} \mathrm{c}^{-1} \mathrm{~d}^{-1}$ previously quoted in Ireland [15]. The average domestic wastewater generation measured on the study site was $662.4 \mathrm{~L} \mathrm{~d}^{-1}$ (which equates to a daily per capita load of 110.4 $\mathrm{L} \mathrm{d}^{-1}$ ) which is in line with similar investigations recently carried out on other test sites in unsewered areas throughout Ireland [8]. Hence, it appears the assumption of $180 \mathrm{~L} \mathrm{c}^{-1} \mathrm{~d}^{-1}$ in the Irish EPA guidelines (EPA, 2000) grossly over-predicts the average wastewater production in such one-off dwellings with typical sized family units, although there were occasional days $(10.5 \%$ of the trial period) when the wastewater flow rates matched or exceeded this value. The mean split of the total on-site effluent discharging to the trenches and to the reed bed 
was $54 \%\left(357.6 \mathrm{~L} \mathrm{~d}^{-1}\right)$ to $46 \%\left(304.7 \mathrm{~L} \mathrm{~d}^{-1}\right)$, respectively, over the course of the trial period.

\subsection{Method of soil moisture sample analysis and effect of dilu- tion by recharge}

As chloride $(\mathrm{Cl})$ does not play a significant role in any geochemical reactions [16], its indicative use in the research was as a tracer to ascertain the extent of the wastewater effluent spread across the percolation area. The results of the laboratory analysis for $\mathrm{Cl}$ at the various sample positions along all sets of trenches were averaged at the same depth plane at which they were recorded. A clear indication could thus be found of any potential differences in loading rates between sampling distances on the same depth plane, thus highlighting any variances within the plane.

Analysis of the $\mathrm{Cl}$ data across the percolation trenches receiving STE revealed consistent effluent loading at the 0,5 and $10 \mathrm{~m}$ sample positions along all three depth planes. This was in contrast to the 15 and $20 \mathrm{~m}$ sample positions where steadily low $\mathrm{Cl}$ concentrations suggested the effluent had not reached these points. This is illustrated in Fig. 4 for the $0.35 \mathrm{~m}$ depth plane. The optimum method of analysing the STE attenuation was therefore by comparing the average loading rates for each parameter across each depth plane $(0.35 \mathrm{~m}, 0.65 \mathrm{~m}$ and $0.95 \mathrm{~m})$ along the first $10 \mathrm{~m}$ of percolation trench. Further scrutiny of the soil moisture tension values from the tensiometers installed at the front $(2.5 \mathrm{~m})$, middle $(7.5 \mathrm{~m})$ and end $(17.5 \mathrm{~m})$ of the same set of trenches showed that the effect of dilution by recharge events on contaminant concentrations on the first half of the percolation area $(0-10$ $\mathrm{m})$ was minimal. This is highlighted by the little response of the tensiometers at the $2.5 \mathrm{~m}$ (Fig. 5) and $7.5 \mathrm{~m}$ positions during periods of effective rainfall. As such, physical, chemical and biological processes were the predomi- nant mechanisms in the attenuation of effluent at the 0,5 and $10 \mathrm{~m}$ sample positions. This was in contrast to the 15 and $20 \mathrm{~m}$ sample positions where it was suspected little effluent had been recorded. At the $17.5 \mathrm{~m}$ point in the percolation area, the tensiometers reacted prominently to the variations in effective rainfall over the sampling period.

Similar $\mathrm{Cl}$ analysis was also carried out on the percolation trenches receiving RBE which showed that the majority of the wastewater had been recorded within the first $5 \mathrm{~m}$ of trench length (Fig. 6.). The trend of more pronounced $\mathrm{Cl}$ loading at the front of these trenches is due to the reduced organic load as a result of the additional treatment provided by the reed bed. This has inhibited the formation of an extensive biomat preventing distribution of the effluent along the base of the trenches. This poor spread could also have been aided by the hydraulic loading rate although mass balance measurements across the reed bed show the average discharge to the receiving trenches to be only marginally lower than the STE flow entering the corresponding set of percolation trenches (ratio 1 : 1.04). Tensiometer readings on this set of trenches also conclusively show the prominent effect of recharge on those areas not thought to be receiving much effluent (Fig. 7.). In contrast, soil moisture tension values varied little in response to effective rainfall at the front of the trenches. The optimum method of analysing the RBE attenuation was therefore by comparing the average loading rates for each parameter across each depth plane $(0.35 \mathrm{~m}, 0.65 \mathrm{~m}$ and $0.95 \mathrm{~m})$ along the first $5 \mathrm{~m}$ of percolation trench.

\subsection{Chemical analysis}

Tables 2 and 3 list the average loading rates of each chemical parameter across both the reed bed and the designated depth planes through both sets of percola-

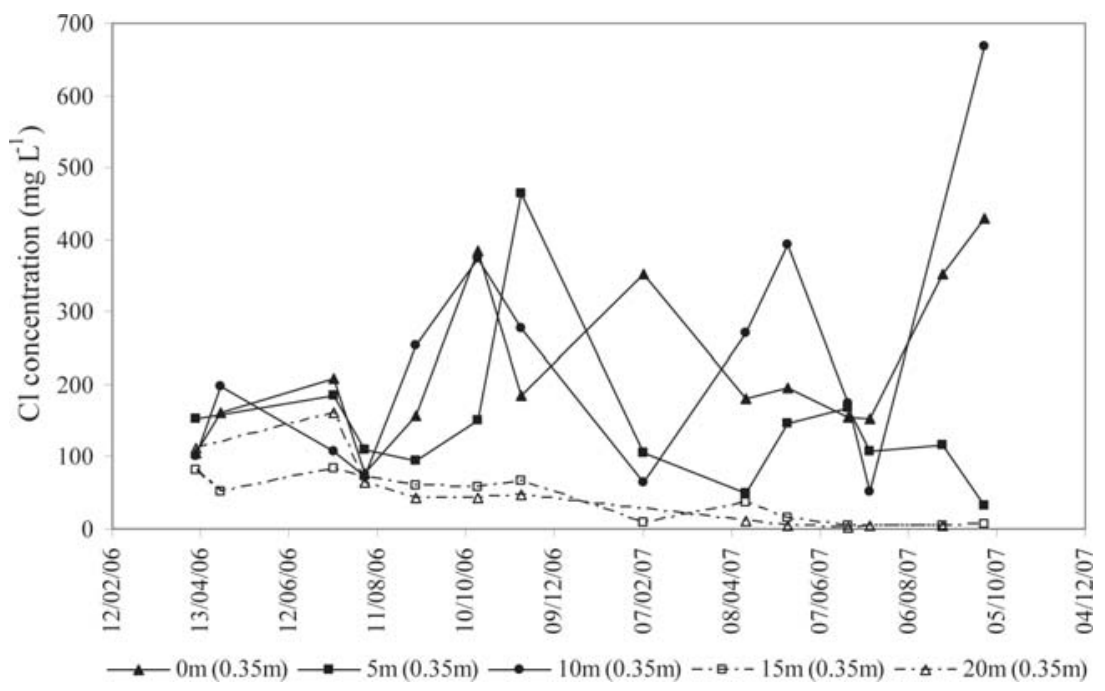

Fig. 4. Average $\mathrm{Cl}$ concentrations at $0.35 \mathrm{~m}$ depth plane across all sample positions on percolation trenches receiving STE. 


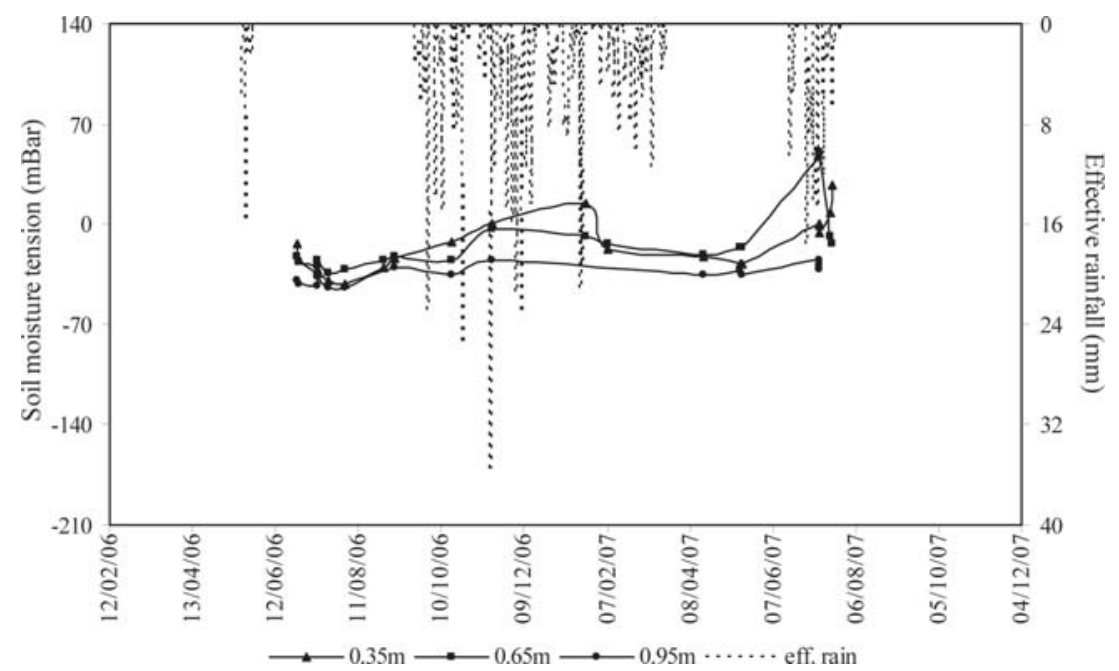

Fig. 5. Soil moisture tension plotted against effective rainfall for the $2.5 \mathrm{~m}$ tensiometer position along the percolation trenches receiving STE.

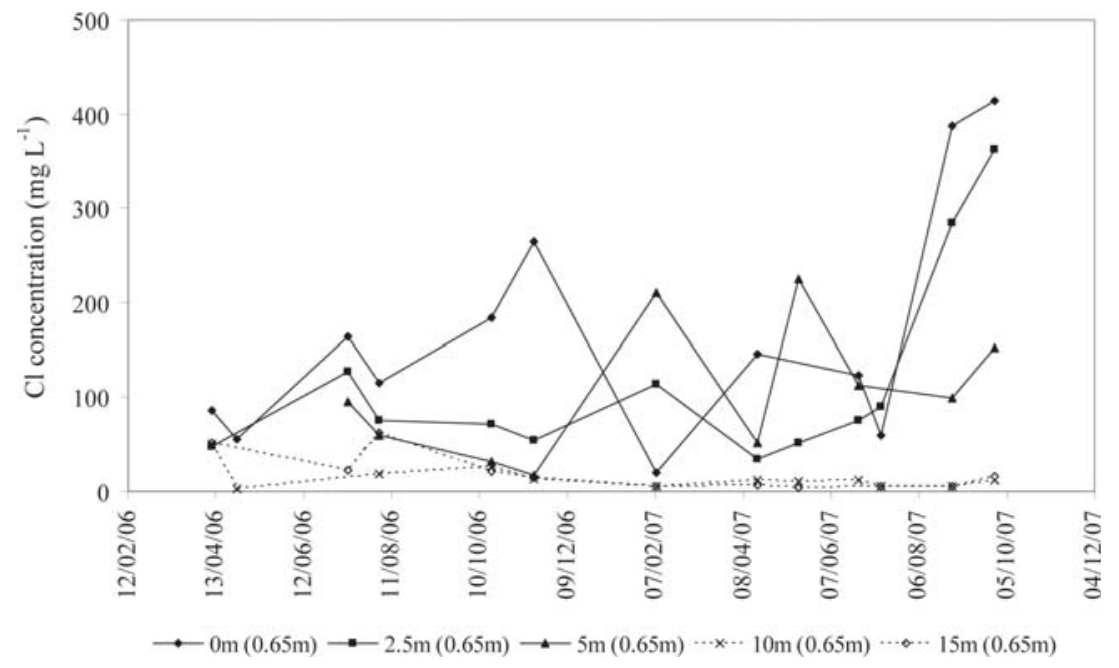

Fig. 6. Average $\mathrm{Cl}$ loading rates at $0.65 \mathrm{~m}$ depth plane across all sample positions on percolation trenches receiving $\mathrm{RBE}$.

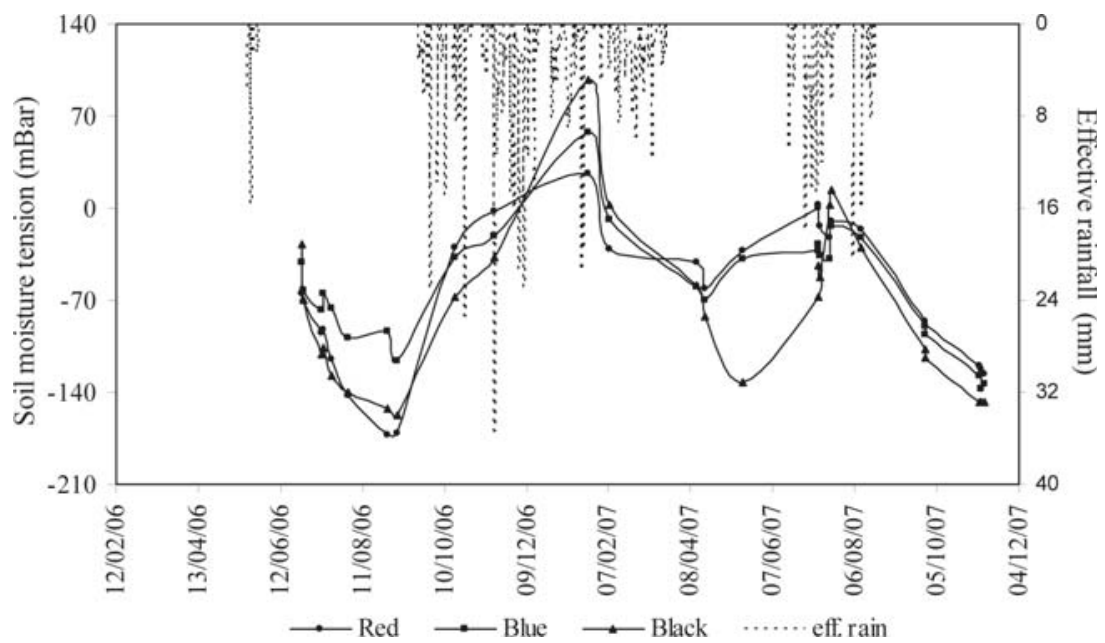

Fig. 7. Soil moisture tension plotted against effective rainfall for the $12.5 \mathrm{~m}$ tensiometer position along the percolation trenches receiving RBE. 
Table 2

Average loading rates of chemical parameters across the percolation trenches receiving STE

\begin{tabular}{lcccc}
\hline Parameter & \multicolumn{4}{l}{ Loading rate $\left(\mathrm{g} \mathrm{d}^{-1}\right)$} \\
\cline { 2 - 5 } & STE & $0.3 \mathrm{~m}$ plane & 0.6 m plane & $1.0 \mathrm{~m}$ plane \\
\hline COD & 221 & 46.2 & 35.4 & 36.3 \\
$\mathrm{NH}_{4}-\mathrm{N}$ & 28.7 & 5 & 2 & 0.6 \\
$\mathrm{NO}_{2}-\mathrm{N}$ & 0.1 & 0.1 & 0.1 & 0.1 \\
$\mathrm{NO}_{3}-\mathrm{N}$ & 0.4 & 9.3 & 10 & 11 \\
Ortho-P & 5.6 & 0.3 & 0.1 & 0.1 \\
pH & 7.5 & 7.9 & 8.0 & 8.0 \\
\hline
\end{tabular}

Table 3

Average loading rates of chemical parameters across the percolation trenches receiving RBE

\begin{tabular}{lccccc}
\hline Parameter & \multicolumn{6}{l}{ Loading rate $\left(\mathrm{g} \mathrm{d}^{-1}\right)$} \\
\cline { 2 - 6 } & RBI & RBE & $\begin{array}{r}0.3 \mathrm{~m} \\
\text { plane }\end{array}$ & $\begin{array}{c}0.6 \mathrm{~m} \\
\text { plane }\end{array}$ & $\begin{array}{c}1.0 \mathrm{~m} \\
\text { plane }\end{array}$ \\
\hline $\mathrm{COD}$ & 173 & 83 & 20.8 & 20.0 & 18.5 \\
$\mathrm{NH}_{4}-\mathrm{N}$ & 23.9 & 22.3 & 0.6 & 0.5 & 0.3 \\
$\mathrm{NO}_{2}-\mathrm{N}$ & 0.1 & 0.02 & 0.1 & 0.1 & 0.03 \\
$\mathrm{NO}_{3}-\mathrm{N}$ & 0.3 & 0.1 & 13.9 & 11.4 & 8.6 \\
Ortho-P & 4.4 & 2.6 & 0.2 & 0.3 & 0.2 \\
pH & 7.5 & 7.4 & 8.3 & 8.1 & 8.1 \\
\hline
\end{tabular}

tion trenches. The concentrations from the percolation trenches receiving STE were averaged over the 0,5 and $10 \mathrm{~m}$ sample positions, while the concentrations from the samples collected at the $0,2.5$ and $5 \mathrm{~m}$ lysimeter positions were averaged from the trenches receiving RBE.

The installation of the HF reed bed as a secondary treatment system has reduced the organic loading on the subsequent percolation area by $52 \%$. When compared with comparable stand alone secondary treatment systems on the Irish market (e.g. peat filter) [8], the reed bed appears to under-perform considerably with regard to organic removal. An average COD effluent concentration of $230 \mathrm{mg} \mathrm{L}^{-1}$ suggests it to be on the high side of a secondary treated effluent. A noticeable layer of biomass at the inlet of the bed emerged over time which clogged the system and also encouraged intermittent surface flows. A subsequent dye tracer test using 20\% rhodamine (RWT) resulted in a peak breakthrough time of 6.7 days, compared to a nominal HRT of 9.3 days. This indicates potential channelling in the reed bed has compromised its full treatment capability despite multiple inlet feeds. Similar breakdown in COD over the first $0.35 \mathrm{~m}$ of unsaturated subsoil is seen to occur for both effluent strengths (79\% STE; 75\% RBE). While it is as- sumed aerobic heterotrophic biodegradation and physiochemical processes play some part in the rapid organic load reduction, predominant breakdown is presumably due to the attenuation and filtering capacity of the formed biomat layer. With increasing depth, little additional COD removal occurs on both sets of trenches with those receiving STE recording an organic load approximately twice that of the trenches receiving RBE just above the potential discharge point to groundwater (0.95 m plane).

TKN measurements at the septic tank outlet clearly showed that the majority of the nitrogen $(80 \%)$ in the raw effluent underwent ammonification in converting to its inorganic $\mathrm{NH}_{4}^{+}-\mathrm{N}$ form. Clear signs of nitrification coupled with the greatest reduction in total inorganic-N load were noted between the point of entry and $0.35 \mathrm{~m}$ depth plane in the percolation trenches receiving STE. A load reduction of $50 \%$ was achieved, with only an additional $9 \%$ denitrification by the $0.95 \mathrm{~m}$ plane. In fact, average total inorganic- $\mathrm{N}$ loads at the point of potential discharge to groundwater were remarkably similar for both levels of treatment with $11.8 \mathrm{~g} \mathrm{~d}^{-1}$ passing the $0.95 \mathrm{~m}$ depth beneath the trenches receiving STE, compared to $9.0 \mathrm{~g} \mathrm{~d}^{-1}$ for the trenches receiving RBE. The failure of the HF reed bed to produce a nitrified effluent, or more significantly, provide any appreciable reduction in nitrogen load has resulted in similar N-loads being discharged to subsoil for both levels of treatment. Poor denitrification with depth may have occurred due to the excessive percolation rate of the effluent in the unsaturated subsoil with critical anoxic zones bypassed. Even if localised saturated conditions existed within the subsoil, the organic load of the percolating effluent may not have been sufficient to support the facultative heterotrophs required for denitrification. Of additional note was the worrying impact the whole treatment system had on nitrate $\left(\mathrm{NO}_{3}-\mathrm{N}\right)$ levels in the groundwater immediately downstream. A tenfold increase $\left(4 \mathrm{mg} \mathrm{L}^{-1}\right.$ to $40 \mathrm{mg} \mathrm{L}^{-1}$ $\mathrm{NO}_{3}^{-}$) in average concentrations was found between U/S and $\mathrm{D} / \mathrm{S}$ groundwater monitoring points during the sampling period.

The attenuation of ortho-P within the subsoil treatment system is a function of the soil's texture and mineralogy while its removal from the percolating effluent is controlled by soil adsorption and mineral precipitation. The ability of a soil to fix phosphorous is highly dependent on its clay content. It was rather surprising, therefore, to find low concentrations of ortho-P in the top layer of the subsoil and throughout given its freely draining nature. A reduction in load of $95 \%$ was measured between the STE and the $0.3 \mathrm{~m}$ plane (Site A) coupled with a $92 \%$ drop between the RBE and $0.3 \mathrm{~m}$ plane. It has been suggested that the P-removal efficiency with respect to sands is often high initially but then decreases after some time after the P-sorption capacity of the sand is used up [17]. The more likely reason, however, for the initial P-reduction in the soil can be found in the on-site trial 
Table 4

Concentrations of and reductions in E. coli across reed bed and trench depth planes

\begin{tabular}{|c|c|c|c|c|c|c|c|}
\hline \multicolumn{2}{|l|}{ E. coli count } & \multicolumn{6}{|c|}{ No. of samples with E. coli concentration (MPN $100 \mathrm{~mL}^{-1}$ ) } \\
\hline $\begin{array}{l}\text { Average } \\
\left(\text { MPN } 100 \mathrm{~mL}^{-1}\right)\end{array}$ & $\begin{array}{l}\text { Log-unit } \\
\text { reduction }\end{array}$ & & $\begin{array}{l}\text { No. of } \\
\text { samples }\end{array}$ & $<10$ & $10-100$ & $100-1000$ & $>1000$ \\
\hline $5.62 \times 10^{6}$ & & STE trenches & & & & & \\
\hline \multirow[t]{6}{*}{$6.92 \times 10^{4}$} & 1.9 & $0.3 \mathrm{~m}$ plane & 47 & 42 & 4 & 1 & 0 \\
\hline & & $0.6 \mathrm{~m}$ plane & 37 & 32 & 2 & 3 & 0 \\
\hline & & $1.0 \mathrm{~m}$ plane & 41 & 39 & 2 & 0 & 0 \\
\hline & & RBE trenches & & & & & \\
\hline & & $0.3 \mathrm{~m}$ plane & 42 & 40 & 2 & 0 & 0 \\
\hline & & $0.6 \mathrm{~m}$ plane & 57 & 55 & 2 & 0 & 0 \\
\hline
\end{tabular}

hole where, on closer inspection, it was noted that an overlying layer of SILT/CLAY had slightly protruded to below the invert of the percolation trenches and as such the clay content of the subsoil initially receiving effluent was increased locally. A combination of sorption onto the media and biomass growth is said to enhance P-removal in the early stages of a wetland which may be suggestive of the $40 \%$ decrease in load across the reed bed. The nutrient uptake, mobilisation and storage by the macrophyte roots and rhizomes is thought to be negligible given their limited growth and expansion in the bed substrate.

\subsection{Bacteriological analysis}

Table 4 presents the E. coli concentrations measured at the septic tank and reed bed outlet in tandem with measurements from both sets of percolation trenches.

The installation of the HF reed bed has greatly reduced the bacterial load on the subsequent trenches with an average 2-3 log-unit removal (99.5\%) in total coliforms and 1.9 log-unit removal (99\%) in E. coli reported. Despite the impressive performance, relatively high concentrations of pathogens still remain in the RBE which would deem it unsuitable for discharge to groundwater prior to further treatment in the subsoil.

The bacteriological results from the percolation trenches underline the impressive ability of the highly permeable subsoil and its associated biomat to remove enteric bacteria from the percolating effluent. There were, however, isolated incidences of E. coli contamination with depth in both sets of trenches. Two of the lysimeters on the $0.65 \mathrm{~m}$ depth plane of the percolation area receiving STE experienced high E. coli counts (>100 MPN $100 \mathrm{~mL}^{-1}$ ) on an early sampling date. However, a reduction in concentration with time was evident at this position suggesting the initial occurrence may have been due to the presence of a preferential flowpath which acted as an open pathway for the bacteria to the lysimeter's porous cup but which became blocked by the development of the biofilm over time thereafter. Negligible E. coli readings were also recorded along the percolation trenches receiving RBE with depth apart from isolated incidences of bacteriological contamination on the $0.95 \mathrm{~m}$ depth plane. Analysis of soil samples according to [18] at this depth showed the lysimeter cup to be on the boundary of a sandy SILT/sandy GRAVEL medium. With the subsoil having a high sand content, it is possible that with an associated large percentage of pore spaces, bacteria migration through the local subsoil may have occurred. Coupled with this is the likelihood that the reduced biomat formation under the trenches receiving RBE had the effect of increasing the hydraulic conductivity and load per unit area. The occurrence of such an incident had a resulting negative impact on the groundwater quality at this time with a high of $360 \mathrm{MPN} 100 \mathrm{ml}^{-1}$ recorded at the D/S groundwater monitoring point.

\section{Conclusions}

Analysis has shown the biomat development under the percolation trenches of an on-site wastewater treatment system to differ with applied effluent strength. The effluent from the reed bed, with its reduced organic content, reached only the front ( $0-5 \mathrm{~m}$ at most) of the percolation trenches in contrast to the trenches receiving highly concentrated STE where the flow had spread to a distance of $10 \mathrm{~m}$. Close examination of the reduction and removal of both chemical constituents and microbial indicator organisms from separately applied STE and RBE at various depths across the freely-draining percolation area show there to be similar performance, especially in nitrogen and bacterial removal. The evidence from this research indicates that the majority of organic, ortho-P and inorganic-N load removal occurs as a result of both the aerobic conditions in the distribution gravel around the percolation pipe and the workings of the biomat within the first $0.35 \mathrm{~m}$ of the subsoil of both sets of per- 
colation trenches. Denitrification with depth has shown to be poor given the freely draining nature of the subsoil with subsequent high N-loads discharged to groundwater.

The performance of the HF reed bed as a secondary treatment system has been compromised by the occurrence of clogging at the inlet and potential short-circuiting of the system. As such, it has been shown to be very limiting in an Irish context with regard to organic removal when the STE is highly concentrated (max. COD concentration in the STE measured at $\left.940 \mathrm{mg} \mathrm{L}^{-1}\right)$. Given the associated lack of nitrification and nominal total-N load removal across the bed, further treatment by means of a vertical flow (VF) reed bed or similar nitrifying system is recommended prior to infiltration in such a permeable subsoil.

\section{Acknowledgements}

The authors wish to acknowledge the Irish Environmental Protection Agency for funding this research study under the Environmental Research Technological Development and Innovation (ERTDI) Programme as part of the National Development Plan 2000-2006.

\section{References}

[1] Department of the Environment and Local Government (DoELG), Environmental Protection Agency (EPA) and Geological Survey of Ireland (GSI), Groundwater Protection Schemes, Department of the Environment and Local Government, Environmental Protection Agency and Geological Survey of Ireland, 2004.

[2] Environmental Protection Agency (EPA), Water Quality in Ireland 2001-2003. Environmental Protection Agency, 2005, Wexford, Ireland.

[3] R.L. Siegrist and S. Van Cuyk, Wastewater soil absorption systems: the performance effects of process and environmental conditions. Proc. 9th Nat. Sym. on Individual and Small Com- munity Sewage Treatment, ASAE, St. Joseph, MI, Fort Worth, Texas, USA, 2001, pp. 41-51.

[4] Environmental Protection Agency (EPA), Wastewater Treatment Manuals: Treatment Systems for Single Houses. Environmental Protection Agency, 2000, Wexford, Ireland.

[5] J. Mulqueen and M. Rodgers, Percolation testing for hydraulic conductivity of soils for percolation areas. Wat. Res., 35 (2001) 3909-3915.

[6] J. Bouma, W.A. Ziebell, W.G. Walker, P.G. Olcutt, E. McCoy and F.D. Hole, Soil absorption of septic tank effluent, Extension Circular No. 20, 1972, University of Wisconsin, Madison.

[7] C. Bitton and C.P. Gerba, Groundwater Pollution Microbiology, John Wiley \& Sons Inc, 1984.

[8] L. Gill, C.Ó. Súilleabháin, P. Johnston and B. Misstear, An investigation into the performance of subsoils and stratified sand filters for the treatment of wastewater from on-site systems. Research Project 2000-MS-15-M1 Final Report, Environmental Protection Agency, Wexford, Ireland, 2005.

[9] R.L. Siegrist, Soil clogging during subsurface wastewater infiltration as affected by effluent composition and loading rate. J. Environ. Qual., 16 (1987) 181-187.

[10] M. Healy and A.M. Cawley, Wetlands and aquatic processes nutrient processing capacity of a constructed wetland in Western Ireland. J. Environ. Qual., 31 (2002) 1739-1747.

[11] L. Davison, T. Headley and K. Pratt, Aspects of design, structure, performance and operation of reed beds - eight years experience in North Eastern New South Wales, Australia. Wat. Sci. Tech., 51 (2005) 129-138.

[12] J. Vyzamal, Removal of $\mathrm{BOD}_{5}$ in constructed wetlands with horizontal subsurface flow: Czech experience. Wat, Sci. Tech., 40 (2001) 133-138.

[13] J. Griggs and N. Grant, Reed Beds for the Treatment of Domestic Wastewater. CRC, London, 2001.

[14] P.F. Cooper, G.D. Job, M.B. Green and R.B.E. Shutes, Reed Beds and Constructed Wetlands for Wastewater Treatment. Water Research Centre (WRc), Swindon, UK, 1996.

[15] N.F. Gray, Composition of septic tank effluent. In The GSI Groundwater Newsletter No. 27, June 1995.

[16] T.J. Marshall, J.W. Holmes and C.W. Rose, Soil Physics, Cambridge University Press, UK, 1999.

[17] C.A. Arias, M. Del Bubba and H. Brix, Phosphorous removal by sands for use as media in subsurface flow constructed reed beds. Wat. Resources, 35 (2001) 1159-1168.

[18] British Standards Institute, BS 5930-1981 Code of Practice for Site Investigations, British Standards Institute, London, 1981. 